\title{
PENERAPAN THINK-PAIR-SHARE DITINJAU DARI KREATIVITAS BELAJAR MATEMATIKA SISWA
}

\author{
Henry Suryo Bintoro \\ Universitas Muria Kudus \\ Gondangmanis Bae Kudus 59352 \\ henrysuryo@yahoo.co.id
}

\begin{abstract}
ABSTRAK
Tujuan penelitian ini (1) untuk mengetahui apakah metode Think-Pair-Share (TPS) menghasilkan prestasi belajar matematika yang lebih baik daripada metode ekspositori, (2) untuk mengetahui apakah prestasi belajar matematika siswa yang mempunyai kreativitas belajar matematika lebih tinggi lebih baik dari siswa yang mempunyai kreativitas belajar matematika lebih rendah, (3) untuk mengetahui apakah terdapat interaksi antara metode TPS dan kreativitas belajar matematika siswa terhadap prestasi belajar matematika siswa.

Penelitian ini merupakan penelitian eksperimen semu dengan desain faktorial $2 \times 3$. Uji hipotesis yang digunakan adalah ANAVA dua jalan dengan sel tak sama. Dengan $\alpha=0,05$ menunjukkan (1) metode TPS menghasilkan prestasi belajar matematika yang lebih baik daripada penggunaan metode ekspositori, (2) prestasi belajar matematika siswa yang mempunyai kreativitas belajar matematika lebih tinggi lebih baik dari siswa yang mempunyai kreativitas belajar matematika lebih rendah, (3) tidak terdapat interaksi antara metode pembelajaran dan kreativitas belajar matematika siswa terhadap prestasi belajar matematika siswa.
\end{abstract}

Kata kunci: Think-Pair-Share, Kreativitas, Pembelajaran Matematika

\section{ABSTRACT}

This research target are (1) to know whether "Think-Pair-Share" (TPS) method can make a better achievement in learning mathematics than using expository method, (2) to know whether the achievement in learning mathematics of the students who have more creativities will be better than those who have less creativities in learning mathematics, (3) to know whether there are any interaction between teaching method and the student' mathematics learning creativity to the students' mathematics learning achievement.

This research is as quasi experimental research with $2 \times 3$ factorial designs. Hypothesis test using two way ANAVA with different cell. With $\alpha=0.05$ shows (1) TPS method resulting a better achievement in learning mathematic than using the expository method, (2) the achievement in learning mathematics of the students who have higher creativities in learning mathematics is better than those who have lower creativities in learning mathematics, (3) there aren't any interaction between teaching method and the student' mathematics learning creativity to the students' mathematics learning achievement.

Key word: Think-Pair-Share, Creativities, mathematics teaching.

\section{PENDAHULUAN}

Matematika merupakan ilmu dasar (basic science) yang berkembang pesat baik materi maupun kegunaannya di dunia ilmu pengetahuan dan teknologi. Namun ironisnya kualitas pendidikan di Indonesia masih sangat rendah, khususnya untuk mata pelajaran matematika. Salah satu usaha yang harus ditempuh untuk perbaikan dan pengembangan kualitas pendidikan khususnya pembelajaran matematika, diantaranya perbaikan dan penyempurnaan sistem pendidikan dan semua aspek yang tercakup dalam pembelajaran matematika.

Salah satu penyebab kesulitan siswa dalam belajar matematika kemungkinan adalah metode mengajar guru yang tidak sesuai dengan kondisi siswa maupun pokok bahasan yang disampaikan. Oleh karena itu, dalam proses belajar mengajar hendaknya digunakan metode yang tepat.

Materi faktorisasi suku aljabar diajarkan di SMP kelas VIII semester I. Materi ini melibatkan pemahaman konsep-konsep 
yang lebih banyak dibanding materi matematika lainnya. Pada materi faktorisasi suku aljabar meskipun terdapat banyak rumus, tetapi kalau siswa tidak memahami konsep sebenarnya maka siswa akan kesulitan untuk menerima materi tersebut.

Berbagai metode yang bervariasi dapat dikembangkan dalam pembelajaran matematika. Salah satu metode yang dapat diterapkan adalah pendekatan struktural metode "Think-Pair-Share" (TPS). Pendekatan struktural metode "Think-PairShare" (TPS) memungkinkan bagi siswa untuk mencapai hasil belajar yang optimal karena siswa dapat belajar. Dalam metode kooperatif ini siswa dibagi dalam kelompok-kelompok kecil berpasangan agar lebih menunjang interaksi antar siswa, dan siswa dengan guru. Tiap kelompok melakukan diskusi untuk memecahkan masalah yang diberikan guru. Kemudian anggota yang akan mewakili kelompoknya untuk memaparkan hasil diskusi dipilih secara acak oleh guru, sehingga setiap anggota kelompok memiliki tanggung jawab individual, artinya setelah melakukan diskusi untuk menemukan jawaban, juga memastikan setiap anggota kelompok mengetahui dan memahami jawaban tersebut. Metode ini dapat membantu meningkatkan penguasaan akademis siswa, memberikan waktu kepada siswa untuk berpikir dan merespon serta saling membantu satu sama lain.

Rendahnya prestasi belajar matematika siswa tidak hanya dipengaruhi oleh metode mengajar saja, tetapi juga bagaimana kreativitas siswa dalam mempelajari mata pelajaran matematika. Tingginya kreativitas belajar siswa dapat berakibat pada tingginya prestasi belajar matematika, begitu pula sebaliknya kreativitas belajar siswa yang rendah dapat berakibat pada rendahnya prestasi belajar matematika siswa. Dengan demikian kreativitas pada saat belajar matematika sangat penting dilakukan untuk meningkatkan prestasi belajar matematika.

Masalah dalam penelitian ini adalah 1). Apakah pendekatan struktural metode "Think-Pair-Share" (TPS) dapat menghasilkan prestasi belajar matematika yang lebih baik daripada penggunaan metode ekspositori pada pokok bahasan faktorisasi suku aljabar? 2). Apakah prestasi belajar matematika siswa yang mempunyai kreativitas belajar matematika lebih tinggi lebih baik dari pada siswa yang mempunyai kreativitas belajar matematika lebih rendah pada pokok bahasan faktorisasi suku aljabar? 3). Apakah prestasi belajar matematika siswa antara siswa yang diberikan pendekatan pendekatan struktural metode "Think-Pair-Share" (TPS) dan metode ekspositori konsisten untuk tiap-tiap kreativitas belajar siswa, dan perbedaan prestasi belajar matematika siswa antara siswa dengan kreativitas yang tinggi, sedang dan rendah konsisten untuk tiap-tiap metode pembelajaran?

Tujuan penelitian ini adalah 1). Untuk mengetahui apakah pendekatan struktural metode "Think-Pair-Share" (TPS) dapat menghasilkan prestasi belajar matematika yang lebih baik daripada penggunaan metode ekspositori pada pokok bahasan faktorisasi suku aljabar? 2). Untuk mengetahui apakah prestasi belajar matematika siswa yang mempunyai kreativitas belajar matematika lebih tinggi lebih baik dari pada siswa yang mempunyai kreativitas belajar matematika lebih rendah pada pokok bahasan faktorisasi suku aljabar? 3). Untuk mengetahui apakah prestasi belajar matematika siswa antara siswa yang diberikan pendekatan pendekatan struktural metode "Think-PairShare" (TPS) dan metode ekspositori konsisten untuk tiap-tiap kreativitas belajar siswa, dan perbedaan prestasi belajar matematika siswa antara siswa dengan kreativitas yang tinggi, sedang dan rendah konsisten untuk tiap-tiap metode pembelajaran?

Manfaat penelitian ini adalah 1). Memberi masukan kepada guru ataupun calon guru matematika tentang penggunaan pendekatan struktural metode "Think-PairShare” (TPS) dalam pembelajaran matematika pada pokok bahasan faktorisasi suku aljabar. 2). Sebagai bahan pertimbangan dalam perbaikan pelaksanaan kegiatan pembelajaran yang dilakukan oleh guru matematika. 3). Dapat memberi gambaran bagi guru dan calon guru bahwa pengembangan kreativitas mengajar matematika dapat menumbuhkan semangat belajar matematika siswa dan mendukung proses kreatif siswa dalam belajar matematika. 4). Sebagai bahan pertimbangan dan masukan bagi penelitian sejenis dengan subyek dan tempat penelitian yang berbeda.

Prestasi adalah bukti atau hasil usaha yang telah dicapai olah seseorang setelah melaksanakan usaha sesuai dengan 
kemampuan yang dimilikinya. Belajar berarti membentuk makna atau menemukan informasi bermakna dimana aktivitas tersebut menghasilkan sesuatu yang baru. Makna diciptakan oleh siswa dari apa yang mereka lihat, dengar, rasakan, dan alami, yang dipengaruhi oleh pengertian yang telah ia punyai. Proses belajar yang sebenarnya terjadi pada waktu skema seseorang dalam keraguan yang merangsang pemikiran lebih lanjut.

Prestasi belajar adalah hasil usaha yang dicapai siswa dalam membentuk makna, penguasaan pengetahuan, serta keterampilan berkat pengalaman dan latihan dalam proses belajar yang dinyatakan dalam bentuk angka, huruf, maupun simbol yang mencerminkan hasil yang sudah dicapai oleh setiap siswa dalam periode tertentu. Di dalam penelitian ini prestasi belajar dinyatakan dalam bentuk angka.

Matematika adalah ilmu tentang bilangan-bilangan yang timbul dari pemikiran manusia yang berhubungan dengan idea, proses, dan penalaran. Matematika berupa ilmu tentang struktur yang terorganisasi dimulai dari unsur-unsur yang tidak didefinisikan ke unsurunsur yang didefinisikan, kemudian ke aksioma atau postulat dan akhirnya sampai ke dalil.

Berdasarkan pengertian prestasi belajar dan matematika yang telah diuraikan di atas dapat disimpulkan bahwa prestasi belajar matematika adalah hasil yang telah dicapai siswa dalam proses belajar matematika yang menghasilkan perubahan pada diri siswa yang disebabkan oleh latihan yang terarah dan hasil dari pengalaman serta proses interaksi dari individu, perubahan tersebut berupa pembentukan makna, penguasaan pengetahuan, dan keterampilan yang hasilnya dinyatakan dengan simbol, angka, atau huruf sebagai nilai.

Prestasi belajar matematika dalam penelitian ini yaitu prestasi belajar pada pokok bahasan faktorisasi suku aljabar.

Metode konvensional yang disebut juga metode tradisional adalah metode mengajar dengan cara-cara lama. Jadi metode konvensional dapat diartikan sebagai pengajaran yang masih menggunakan sistem yang biasa dilakukan yaitu sistem ceramah. Selain metode ceramah, metode pembelajaran yang sering digunakan dalam pembelajaran konvensional adalah metode ekspositori. Dalam metode ekspositori dominasi guru banyak berkurang, karena guru tidak terus bicara saja. Guru bebicara pada awal pembicaraan, menerangkan materi dan memberi contoh pada waktu yang diperlukan, kemudian dilanjutkan dengan memberikan soal latihan.

Dalam penelitian ini metode konvensional yang dipakai adalah menggunakan metode ekspositori.

Pendekatan struktural metode "ThinkPair-Share" (TPS) memiliki prosedur yang ditetapkan secara eksplisit, yaitu:

a) Thinking (berfikir)

Guru memberikan pertanyaan yang berhubungan dengan pelajaran, kemudian siswa diminta untuk memikirkan pertanyaan tersebut secara mandiri untuk beberapa saat.

b) Pairing (berpasangan)

Guru meminta siswa untuk berpasangan dengan siswa yang lain untuk mendiskusikan apa yang telah dipikirkannya pada langkah pertama. Interaksi pada tahap ini diharapkan dapat berbagi jawaban jika telah diajukan suatu pertanyaan atau berbagi ide jika suatu persoalan khusus telah diidentifikasi.

c) Sharing (berbagi)

Guru meminta pasangan-pasangan siswa tersebut untuk berbagi atau bekarja sama dan dilanjutkan sampai beberapa siswa telah mendapat kesempatan untuk melaporkan, paling tidak sekitar seperempat pasangan, tetapi disesuaikan dengan waktu yang tersedia. Pada langkah ini akan menjadi efektif apabila guru berkeliling kelas dari pasangan yang satu ke pasangan yang lain.

Berdasarkan langkah-langkah di atas peneliti menggunakan langkah-langkah pengembangan sebagai berikut:

a) Guru mengorganisasi kelas untuk belajar dan mengarahkan siswa untuk mempersiapkan materi yang telah dipelajari di rumah.

b) Guru memberikan suatu masalah yang berkaitan dengan materi yang akan dipelajari kemudian siswa diminta untuk memikirkan masalah tersebut secara mandiri untuk beberapa saat.

c) Guru mengingatkan siswa pada materi prasyarat dan memberikan penjelasan seperlunya yang berkaitan dengan materi yang akan dipelajari siswa. 
d) Guru membagikan LKS yang berisi pertanyaan atau masalah dan mengarahkan siswa untuk mengerjakan LKS, menjawab pertanyaan, menyelesaikan masalah, melakukan aktivitas, atau mengerjakan tugas secara mandiri.

e) Guru membagi siswa dalam kelompokkelompok dengan anggota 2 orang untuk tiap kelompok.

f) Siswa berpikir bersama-sama dalam kelompok untuk menemukan jawaban dari pertanyaan guru berdasarkan jawaban yang telah mereka peroleh secara mandiri.

g) Guru memanggil kelompok tertentu dan pasangan siswa tersebut memberikan jawabannya pada seluruh anggota kelas dari hasil diskusi yang telah mereka lakukan. Kegiatan tersebut dilanjutkan sampai beberapa siswa telah mendapat kesempatan untuk melaporkan, paling tidak sekitar seperempat pasangan, tetapi disesuaikan dengan waktu yang tersedia.

h) Guru menutup kegiatan belajar mengajar dengan membimbing siswa untuk menyimpulkan materi yang telah dipelajari dan memberikan tugas untuk dikerjakan di rumah.

Kreativitas adalah kemampuan untuk membuat kombinasi-kombinasi baru, atau melihat hubungan-hubungan baru antar unsur, data, atau hal-hal yang sudah ada sebelumnya. Dari uraian juga dijelaskan bahwa belajar matematika adalah suatu aktivitas mental (psikis) yang berlangsung dalam interaksi dengan lingkungan dan menghasilkan perubahan-perubahan, pemahaman serta kecakapan baru lainnya tentang matematika. Sehingga dapat disimpulkan bahwa kreativitas belajar matematika siswa merupakan suatu proses memikirkan berbagai gagasan dalam menghadapi suatu masalah, sebagai proses "bermain" dengan gagasan-gagasan atau unsur-unsur dalam fikiran yang merupakan keasyikan dan penuh tantangan dalam diri siswa terhadap matematika.

Dari pengertian kreativitas belajar matematika tersebut, dengan adanya kreativitas belajar matematika siswa yang tinggi diharapkan akan dapat meningkatkan prestasi belajar matematika siswa. Hal ini akan ditunjang dengan penggunaan pendekatan srtuktural metode "Think-Pair-Share" (TPS) yang diharapkan juga dapat mendorong timbulnya kreativitas belajar dari siswa.

\section{METODE PENELITIAN}

Metode penelitian yang digunakan dalam penelitian ini adalah metode eksperimen semu (quasi-experimental research) dengan desain faktorial $2 \times 3$. Populasi penelitian ini adalah siswa kelas VIII SMP Negeri Kota Surakarta Tahun Pelajaran 2009/2010 yang berjumlah 27 SMP. Teknik pengambilan sampel dilakukan secara stratified cluster random sampling. Sampel dalam penelitian berjumlah 233 responden yang terdiri dari kelompok eksperimen dan kelompok kontrol. Instrumen yang digunakan untuk mengumpulkan data adalah instrumen tes prestasi belajar matematika dan instrumen angket kreativitas belajar matematika siswa. Instrumen tes dan angket diujicobakan sebelum digunakan untuk pengambilan data. Validitas instrumen tes dan angket dilakukan oleh validator, reliabilitas tes diuji dengan rumus KR-20 dan reliabilitas angket diuji dengan rumus Alpha. Teknik analisis data yang digunakan adalah analisis variansi dua jalan dengan sel tak sama. Sebagai persyaratan penelitian dilakukan uji keseimbangan dengan uji- $t$ dan sebagai persyaratan analisis data dilakukan uji normalitas dengan menggunakan metode Lilliefors dan uji homogenitas dengan menggunakan metode Bartlett.

\section{HASIL DAN PEMBAHASAN}

Melalui dua orang validator, yaitu guru SMP Negeri 3 Surakarta dan guru SMP Negeri 22 Surakarta diperoleh bahwa 35 butir tes prestasi dinyatakan valid karena telah memenuhi kriteria yang diberikan. Dengan menggunakan rumus KR-20, diperoleh $\mathrm{r}_{11}=$ 0,820766. Karena $r_{11}=0,820766>0,7$, sehingga instrumen tes dikatakan reliabel. Dari hasil uji daya pembeda menggunakan rumus korelasi produk momen diperoleh 25 soal yang daya pembedanya berfungsi dengan baik. Dari 35 soal tes uji coba prestasi didapat lima soal sukar yaitu nomor 12, 20, 25, 27, dan 28, satu soal mudah yaitu soal nomor 4. Sedangkan yang lainnya termasuk soal yang sedang artinya tidak terlalu mudah dan juga tidak terlalu sukar.

Setelah dilakukan analisis terhadap 35 soal tes uji coba prestasi belajar matematika diperoleh bahwa 10 soal tidak dapat digunakan yaitu nomor $4,12,14,20,23,25,27,28,31$ dan 32. Sehingga penulis hanya menggunakan 25 butir soal untuk penelitian.

Melalui dua orang validator, yaitu guru SMP Negeri 3 Surakarta dan guru SMP 
Negeri 22 Surakarta diperoleh bahwa 40 butir angket dinyatakan valid karena telah memenuhi kriteria yang diberikan. Dengan menggunakan rumus Alpha, diperoleh $\mathrm{r}_{11}=$ 0,830468 . Karena $r_{11}=0,830468>0,70$, sehingga angket dikatakan reliabel. Dari hasil uji konsistensi internal dengan menggunakan rumus korelasi produk momen diperoleh 30 butir yang konsisten sebab $r_{x y}$ dari 30 butir tersebut lebih besar dari 0,3.

Setelah dilakukan analisis terhadap 40 butir soal uji coba angket kreativitas siswa diperoleh bahwa 30 butir soal tersebut dapat digunakan untuk penelitian.

Tabel 1. Deskripsi Data Prestasi Belajar Siswa

\begin{tabular}{|c|c|c|c|c|c|c|c||}
\hline \multirow{3}{*}{ Kelas } & \multicolumn{3}{|c|}{$\begin{array}{c}\text { Ukuran } \\
\text { Tendensi } \\
\text { sentral }\end{array}$} & \multicolumn{4}{c||}{ Ukuran Dispersi } \\
\cline { 2 - 8 } & $\bar{X}$ & Mo & Me & $\begin{array}{c}\text { Skor } \\
\text { min }\end{array}$ & $\begin{array}{c}\text { Skor } \\
\text { maks }\end{array}$ & J & s \\
\hline \hline Kontrol & 53,5 & 52 & 52 & 32 & 88 & 56 & 13,3 \\
\hline Eksperimen & 71,2 & 68 & 72 & 44 & 100 & 56 & 13,5 \\
\hline
\end{tabular}

Tabel 2. Deskripsi Data Kreativitas Belajar Siswa

\begin{tabular}{|c|c|c|c||}
\hline \multirow{2}{*}{ Kategori } & \multirow{2}{*}{ Nilai } & \multicolumn{2}{|c||}{ Jumlah Siswa } \\
\cline { 3 - 4 } & & $\begin{array}{c}\text { Kelas } \\
\text { Eksperimen }\end{array}$ & $\begin{array}{c}\text { Kelas } \\
\text { Kontrol }\end{array}$ \\
\hline \hline Tinggi & $85,4<X$ & 46 & 26 \\
\hline Sedang & $\begin{array}{c}74,9 \leq X \leq \\
85,4\end{array}$ & 47 & 42 \\
\hline Rendah & $X<74,8737$ & 24 & 48 \\
\hline
\end{tabular}

Tabel 3. Hasil Uji Normalitas Kemampuan Awal

\begin{tabular}{|c|c|c|c|c|c|c|c|c|c|}
\hline \multirow{2}{*}{\multicolumn{5}{|c|}{$\begin{array}{c}\text { Tabel 3. Hasil Uji } \\
\text { Awal }\end{array}$}} & \multirow{3}{*}{ Sampel } & \multirow{3}{*}{$\begin{array}{c}\chi^{2} \\
\text { obs }\end{array}$} & \multirow{3}{*}{$\begin{array}{c}\chi^{2} \\
0.05 ; \\
\mathrm{n} \\
\end{array}$} & \multirow{3}{*}{$\begin{array}{c}\text { Keputusa } \\
\mathrm{n}\end{array}$} & \multirow{3}{*}{$\underset{\mathrm{n}}{\mathrm{Kesimpula}}$} \\
\hline & & & & & & & & & \\
\hline \multirow{2}{*}{$\begin{array}{c}\text { Uji } \\
\text { Normalitas }\end{array}$} & \multirow{2}{*}{ Lobs } & \multirow{2}{*}{$\mathrm{L}_{0,05 ; \mathrm{n}}$} & \multirow{2}{*}{$\begin{array}{c}\text { Keputusa } \\
n\end{array}$} & \multirow{2}{*}{$\underset{\mathrm{n}}{\mathrm{Kesimpula}}$} & & & & & \\
\hline & & & & & Metode & & & & \\
\hline \multirow{2}{*}{$\begin{array}{l}\text { Kelas } \\
\text { Eksperime } \\
\mathrm{n}\end{array}$} & \multirow[t]{2}{*}{0,079} & \multirow{2}{*}{$\begin{array}{c}0,08 \\
2\end{array}$} & \multirow{2}{*}{$\underset{\text { diterima }}{\mathrm{H}_{0}}$} & \multirow[t]{2}{*}{ Normal } & Pembelajara & $\begin{array}{c}0,0 \\
3\end{array}$ & $\begin{array}{c}3,8 \\
4\end{array}$ & $\begin{array}{c}\mathrm{H}_{0} \\
\text { diterima }\end{array}$ & Homogen \\
\hline & & & & & Kreativitas & & & & \\
\hline $\begin{array}{l}\text { Kelas } \\
\text { Kontrol }\end{array}$ & 0,081 & $\begin{array}{c}0,08 \\
2\end{array}$ & $\begin{array}{c}\mathrm{H}_{0} \\
\text { diterima }\end{array}$ & Normal & $\begin{array}{l}\text { Belajar } \\
\text { Siswa }\end{array}$ & $\begin{array}{c}0,9 \\
9\end{array}$ & $\begin{array}{c}5,9 \\
9\end{array}$ & $\begin{array}{c}\mathrm{H}_{0} \\
\text { diterima }\end{array}$ & Homogen \\
\hline
\end{tabular}

Berdasarkan tabel di atas, untuk masingmasing sampel ternyata $\mathrm{L}_{\mathrm{obs}}<\mathrm{L}_{0,05 ; \mathrm{n}}$, sehingga $\mathrm{H}_{0}$ diterima. Ini berarti masing-masing sampel berasal dari distribusi normal.

Tabel 4. Hasil Uji Homogenitas Kemampuan Awal

\begin{tabular}{|c|c|c|c|c|c|c|c|c|c|}
\hline \multicolumn{5}{|c|}{ Awal } & \multirow{2}{*}{\multicolumn{5}{|c|}{$\begin{array}{l}\text { variansi-variansi populasi yang dikenai } \\
\text { perlakuan metode mengajar dan variansi- } \\
\text { yariansi kreativitas siswa sama. }\end{array}$}} \\
\hline $\begin{array}{c}\text { Samp } \\
\text { el }\end{array}$ & $\chi_{\text {obs }}^{2}$ & $\begin{array}{c}\chi^{2} \\
0.05 ; n\end{array}$ & $\begin{array}{c}\text { Keputusa } \\
n\end{array}$ & $\underset{n}{\text { Kesimpula }}$ & & & & & \\
\hline Kelas & 0,3495 & 3,841 & $\begin{array}{c}\mathrm{H}_{0} \\
\text { diterima }\end{array}$ & Homogen & \multicolumn{5}{|c|}{$\begin{array}{l}\text { abel 7. Rangkuman Analisis Variansi Dua } \\
\text { Jalan Dengan Sel Tak Sama }\end{array}$} \\
\hline & & & & & & RK & $\bar{F} \mathrm{~F}_{\mathrm{obs}}$ & $\mathrm{F}_{\mathrm{tab}}$ & Keputusan \\
\hline & & & & & Metode & 11936,2 & 85,2049 & 3,8 & Ho \\
\hline
\end{tabular}

Berdasarkan tabel di atas, ternyata harga $\chi_{o b s}^{2}$ $<\chi_{0.05 ; n}^{2}$, sehingga $\mathrm{H}_{0}$ diterima. Ini berarti variansi sampel homogen.

Hasil uji keseimbangan dengan menggunakan uji $\mathrm{t}$ diperoleh $\mathrm{t}_{\text {hit }}=0,4873$ dengan $\mathrm{t}_{0,025 ; v}=1,96$ dan $-\mathrm{t}_{0,025 ; v}=-1,96$. Ternyata diperoleh $\mathrm{t}_{\text {hit }}<\mathrm{t}_{0,025 ; v}$ atau $\mathrm{t}_{\text {hit }}>-$ $\mathrm{t}_{0,025 ; v} \quad$ sehingga dapat disimpulkan bahwa antara kedua kelompok tidak memiliki perbedaan rerata yang berarti atau dapat dikatakan bahwa kedua kelompok dalam keadaan seimbang.

Tabel 5. Hasil Uji Normalitas

\begin{tabular}{||c|c|c|c|c||}
\hline $\begin{array}{c}\text { Uji } \\
\text { Normalitas }\end{array}$ & $\mathrm{L}_{\mathrm{obs}}$ & $\mathrm{L}_{0,05 ; \mathrm{n}}$ & Keputusan & Kesimpulan \\
\hline $\begin{array}{c}\text { Kelompok } \\
\text { Eksperimen }\end{array}$ & 0,0799 & 0,0819 & $\begin{array}{c}\mathrm{H}_{0} \\
\text { diterima }\end{array}$ & Normal \\
\hline $\begin{array}{c}\text { Kelompok } \\
\text { Kontrol }\end{array}$ & 0,0822 & 0,0823 & $\begin{array}{c}\mathrm{H}_{0} \\
\text { diterima }\end{array}$ & Normal \\
\hline $\begin{array}{c}\text { Kreativitas } \\
\text { Tinggi }\end{array}$ & 0,0986 & 0,1044 & $\begin{array}{c}\mathrm{H}_{0} \\
\text { diterima }\end{array}$ & Normal \\
\hline $\begin{array}{c}\text { Kreativitas } \\
\text { Sedang }\end{array}$ & 0,0922 & 0,0939 & $\begin{array}{c}\mathrm{H}_{0} \\
\text { diterima }\end{array}$ & Normal \\
\hline $\begin{array}{c}\text { Kreativitas } \\
\text { Rendah }\end{array}$ & 0,0977 & 0,1044 & $\begin{array}{c}\mathrm{H}_{0} \\
\text { diterima }\end{array}$ & Normal \\
\hline
\end{tabular}

Berdasarkan tabel di atas untuk

masing-masing sampel ternyata $\mathrm{L}_{\mathrm{obs}}<\mathrm{L}_{0,05 ; n}$, sehingga $\mathrm{H}_{0}$ diterima. Ini Berarti masingmasing sampel berasal dari populasi yang berdistribusi normal.

Tabel 6. Hasil Uji Homogenitas

harga $\chi_{o b s}^{2}$ dari kelas yang diberi perlakuan metode mengajar dan kreativitas siswa kurang dari $\chi_{0.05 ; n}^{2}$, sehingga $\mathrm{H}_{0}$ diterima. Ini berarti variansi-variansi populasi yang dikenai

Metode 


\begin{tabular}{||l|c|c|c|c||}
\hline \hline (A) & & & & Ditolak \\
\hline $\begin{array}{l}\text { Kreativitas } \\
(\mathrm{B})\end{array}$ & 4605,1 & 32,8727 & 3,00 & $\begin{array}{c}\text { Ho } \\
\text { Ditolak }\end{array}$ \\
\hline $\begin{array}{l}\text { Interaksi } \\
\text { (AB) }\end{array}$ & 184,2 & 1,3146 & 3,00 & $\begin{array}{c}\text { Ho } \\
\text { Diterima }\end{array}$ \\
\hline Galat & 140,1 & & & \\
\hline
\end{tabular}

Tabel di atas menunjukkan bahwa :

a. Pada efek utama baris (A) $\mathrm{H}_{0}$ ditolak.

Hal ini berarti siswa yang diberi perlakuan pendekatan struktural metode "Think-Pair-Share" (TPS) memiliki prestasi belajar matematika yang berbeda dari siswa yang diberi perlakuan metode ekspositori.

b. Pada efek utama kolom (B) $\mathrm{H}_{0}$ ditolak.

Hal ini berarti terdapat perbedaan prestasi belajar matematika antara siswa dengan kreativitas belajar tinggi, sedang, dan rendah.

c. Pada efek utama interaksi (AB), $\mathrm{H}_{0}$ diterima.

Hal ini berarti perbedaan prestasi dari masing-masing metode pembelajaran konsisten pada masing-masing tingkat kreativitas belajar dan adanya perbedaan prestasi belajar dari masing-masing tingkat kreativitas belajar konsisten pada masing-masing metode pembelajaran.

Tabel 8. Hasil Uji Komparasi Ganda Antar Kolom

\begin{tabular}{|c||c|c|c||c|}
\hline No & $\begin{array}{c}\text { Hipotesis } \\
\text { Nol }\end{array}$ & $\mathrm{F}_{\text {hitung }}$ & $\begin{array}{c}\mathrm{F} \\
\text { tabel }\end{array}$ & Keputusan \\
\hline \hline 1 & $\mu_{1}=\mu_{2}$ & 36,2122 & 6,00 & $H_{0}$ ditolak \\
2 & $\mu_{1}=\mu_{3}$ & 113,9291 & 6,00 & $H_{0}$ ditolak \\
3 & $\mu_{2}=\mu_{3}$ & 27,0970 & 6,00 & $H_{0}$ ditolak \\
\hline
\end{tabular}

Dari uji komparasi ganda antar kolom di atas diperoleh terdapat perbedaan pengaruh antara kreativitas belajar tinggi dan sedang terhadap prestasi belajar matematika siswa, terdapat perbedaan pengaruh antara kreativitas belajar tinggi dan rendah terhadap prestasi belajar matematika siswa dan terdapat perbedaan pengaruh antara kreativitas belajar sedang dan rendah terhadap prestasi belajar matematika siswa. Dari rataan marginalnya $\left(\overline{X_{.1}}=\right.$ $73,2222>61,9326=\overline{X_{.2}}$ ) menunjukkan bahwa siswa yang memiliki kreativitas belajar tinggi prestasi belajarnya lebih baik dibandingkan siswa yang memiliki kreativitas belajar sedang. Untuk $\left(\overline{X_{.1}}=73,2222>\right.$ $\left.52,1667=\overline{X_{.3}}\right)$ menunjukkan bahwa siswa yang memiliki kreativitas belajar tinggi prestasi belajarnya lebih baik dibandingkan siswa yang memiliki kreativitas belajar rendah. Untuk $\left(\overline{X_{.2}}=61,9326>52,1667=\overline{X_{.3}}\right)$ menunjukkan bahwa siswa yang memiliki kreativitas belajar sedang prestasi belajarnya lebih baik dibandingkan siswa yang memiliki kreativitas belajar rendah. Selanjutnya karena $\mathrm{H}_{0 A B}$ diterima maka tidak perlu dilakukan uji komparasi antar sel pada kolom atau baris yang sama.

\section{Hipotesis Pertama}

Dari hasil anava dua jalan sel tak sama diperoleh $\mathrm{F}_{\mathrm{a}}=85,2049>3,84 \quad=\mathrm{F}$ 0,$05 ; 1 ; 227$. Nilai $F_{a}$ terletak di daerah kritik maka $\mathrm{H}_{0 A}$ ditolak berarti terdapat perbedaan pengaruh metode pembelajaran terhadap prestasi belajar matematika pada pokok bahasan faktorisasi suku aljabar. Dari rataan marginalnya $\left(\overline{X_{1}}=71,1795>53,5517=\right.$ $\overline{X_{2}}$ ) menunjukkan bahwa pembelajaran dengan pendekatan struktural metode "ThinkPair-Share" (TPS) menghasilkan prestasi belajar lebih baik dibandingkan metode ekspositori pada pokok bahasan faktorisasi suku aljabar. Hal tersebut sesuai dengan hipotesis teori.

\section{Hipotesis Kedua}

Dari hasil anava dua jalan sel tak sama diperoleh $\mathrm{F}_{\mathrm{b}}=32,8727>3,00 \quad=\mathrm{F}$ 0,05;2;227 . Nilai $F_{b}$ terletak di daerah kritik maka $\mathrm{H}_{0 B}$ ditolak berarti kreativitas belajar matematika siswa berpengaruh terhadap prestasi belajar matematika siswa pada pokok bahasan faktorisasi suku aljabar. Setelah dilakukan uji Scheffe' dapat disimpulkan bahwa siswa yang memiliki kreativitas belajar matematika tinggi prestasi belajarnya berbeda dengan siswa yang memiliki kreativitas belajar matematika sedang dan siswa yang memiliki kreativitas belajar matematika tinggi prestasi belajarnya berbeda dengan siswa yang memiliki kreativitas belajar matematika rendah, serta siswa yang memiliki kreativitas belajar matematika sedang prestasi belajarnya berbeda dengan siswa yang memiliki kreativitas belajar rendah pada pokok bahasan faktorisasi suku aljabar. Dari rataan marginalnya $\left(\overline{X_{.1}}=73,2222>61,9326=\overline{X_{.2}}\right.$ ) menunjukkan bahwa siswa yang memiliki 
kreativitas belajar tinggi prestasi belajarnya lebih baik dibandingkan siswa yang memiliki kreativitas belajar sedang dan dari rataan marginal $\left(\overline{X_{.1}}=73,2222>52,1667=\overline{X_{.3}}\right)$ menunjukkan bahwa siswa yang memiliki kreativitas belajar tinggi prestasi belajarnya lebih baik dibandingkan siswa yang memiliki kreativitas belajar rendah serta dari rataan marginal $\left(\overline{X_{.2}}=61,9326>52,166=\overline{X_{.3}}\right)$ menunjukkan bahwa siswa yang memiliki kreativitas belajar sedang prestasi belajarnya lebih baik dibandingkan siswa yang memiliki kreativitas belajar rendah. Hal tersebut sesuai dengan hipotesis teori.

\section{Hipotesis Ketiga}

Dari hasil anava dua jalan sel tak sama diperoleh $\mathrm{F}_{\mathrm{ab}}=1,3146<3,00 \quad=\mathrm{F}$

0,05;2;227. Nilai $F_{a b}$ tidak terletak di daerah kritik maka $\mathrm{H}_{O A B}$ diterima berarti tidak terdapat interaksi antara metode pembelajaran dan kreativitas belajar terhadap prestasi belajar pada pokok bahasan faktorisasi suku aljabar. Berdasarkan hasil uji hipotesis pertama, pembelajaran dengan menggunakan pendekatan struktural metode "Think-PairShare" (TPS) menghasilkan prestasi belajar lebih baik dibandingkan metode ekspositori. Karena tidak ada interaksi maka hal tersebut juga berlaku pada tiap kategori kreativitas belajar siswa, dalam arti metode pembelajaran pendekatan struktural metode "Think-PairShare" (TPS) akan menghasilkan prestasi belajar lebih baik dibandingkan metode ekspositori untuk setiap kategori kreativitas belajar yang dimiliki siswa. Hal tersebut tidak sesuai dengan hipotesis teori.

\section{Hipotesis Keempat}

Dari hasil anava dua jalan sel tak sama diperoleh $\mathrm{F}_{\mathrm{ab}}=1,3146<3,00=\mathrm{F}_{0,05 ; 2 ; 227}$. Nilai $F_{a b}$ tidak terletak di daerah kritik maka $\mathrm{H}$ ${ }_{O A B}$ diterima berarti tidak terdapat interaksi antara metode pembelajaran dan kreativitas belajar terhadap prestasi belajar pada pokok bahasan faktorisasi suku aljabar. Berdasar uji hipotesis kedua dan uji komparasi ganda, karena tidak ada interaksi, maka karakteristik perbedaan kreativitas belajar akan sama pada setiap metode pembelajaran. Artinya pada metode pembelajaran pendekatan struktural metode "Think-Pair-Share" (TPS) siswa yang memiliki kreativitas belajar tinggi prestasi belajarnya lebih baik daripada siswa yang memiliki kreativitas belajar sedang dan rendah serta siswa yang memiliki kreativitas belajar sedang prestasi belajarnya lebih baik daripada siswa yang memiliki kreativitas belajar rendah. Hal tersebut sesuai dengan hipotesis teori.

\section{Hipotesis Kelima}

Dari hasil anava dua jalan sel tak sama diperoleh $\mathrm{F}_{\mathrm{ab}}=1,3146<3,00 \quad=\mathrm{F}$ 0,$05 ; 2 ; 227$. Nilai $F_{a b}$ tidak terletak di daerah kritik maka $\mathrm{H}_{0 A B}$ diterima berarti tidak terdapat interaksi antara metode pembelajaran dan kreativitas belajar terhadap prestasi belajar pada pokok bahasan faktorisasi suku aljabar. Berdasar uji hipotesis kedua dan uji komparasi ganda, karena tidak ada interaksi, maka karakteristik perbedaan kreativitas belajar akan sama pada setiap metode pembelajaran. Artinya pada metode pembelajaran metode ekspositori siswa yang memiliki kreativitas belajar tinggi prestasi belajarnya lebih baik daripada siswa yang memiliki kreativitas belajar sedang dan rendah serta siswa yang memiliki kreativitas belajar sedang prestasi belajarnya lebih baik daripada siswa yang memiliki kreativitas belajar rendah. Hal tersebut sesuai dengan hipotesis teori.

Keterbatasan Penelitian

Tidak terdapat interaksi antara metode pembelajaran dan kreativitas belajar matematika siswa terhadap prestasi belajar matematika siswa mungkin dikarenakan oleh: siswa kurang disiplin dalam mengikuti kegiatan belajar matematika. Akibatnya sebagian siswa ada yang kurang memperhatikan terhadap materi pelajaran yang disampaikan guru; peneliti kurang memperhatikan pokok bahasan materi yang disampaikan terhadap tingkat kemampuan siswa; adanya variabel bebas lain yang tidak termasuk dalam penelitian ini, misalnya faktor intelegensi, bimbingan belajar, kedisiplinan dalam belajar, latar belakang keluarga, lingkungan dan sebagainya. Akibatnya siswa belum bisa optimal dalam mengikuti proses belajar untuk meningkatkan prestasi belajar pada umumnya dan prestasi belajar matematika pada khususnya.

\section{SIMPULAN}

Berdasarkan kajian teori dan didukung adanya analisis variansi serta mengacu pada perumusan masalah yang telah diuraikan di muka, dapat disimpulkan beberapa hal sebagai berikut: 
1. Metode pembelajaran pendekatan struktural metode "Think-Pair-Share" (TPS) menghasilkan prestasi belajar matematika yang lebih baik dibandingkan dengan metode ekspositori pada pokok bahasan faktorisasi suku aljabar.

2. Terdapat perbedaan prestasi belajar matematika antara siswa yang memiliki kreativitas belajar matematika tinggi dengan siswa yang memiliki kreativitas belajar matematika sedang, terdapat perbedaan prestasi belajar matematika antara siswa yang memiliki kreativitas belajar matematika tinggi dengan siswa yang memiliki kreativitas belajar matematika rendah serta terdapat perbedaan prestasi belajar matematika antara siswa yang memiliki kreativitas belajar matematika sedang dengan siswa yang memiliki kreativitas belajar matematika rendah pada pokok bahasan faktorisasi suku aljabar.

3. Pendekatan struktural metode "ThinkPair-Share" (TPS) menghasilkan prestasi belajar matematika lebih baik daripada penggunaan metode ekspositori pada siswa yang mempunyai kreativitas belajar matematika tinggi, sedang dan rendah.

4. Pada pendekatan struktural metode "Think-Pair-Share" (TPS), siswa yang mempunyai kreativitas belajar matematika tinggi menghasilkan prestasi belajar matematika lebih baik daripada siswa yang mempunyai kreativitas belajar matematika sedang dan rendah serta siswa yang mempunyai kreativitas belajar matematika sedang menghasilkan prestasi belajar matematika lebih baik daripada siswa yang mempunyai kreativitas belajar matematika rendah.

5. Pada metode ekspositori, siswa yang mempunyai kreativitas belajar matematika tinggi menghasilkan prestasi belajar matematika lebih baik daripada siswa yang mempunyai kreativitas belajar matematika sedang dan rendah serta siswa yang mempunyai kreativitas belajar matematika sedang menghasilkan prestasi belajar matematika lebih baik daripada siswa yang mempunyai kreativitas belajar matematika rendah.

Berdasarkan kesimpulan di atas, ada beberapa hal yang perlu peneliti sarankan, yaitu:

1. Bagi Pendidik a. Dalam penyampaian materi pelajaran matematika, guru dan calon guru bidang studi matematika perlu memperhatikan adanya pemilihan metode pembelajaran yang tepat yaitu sesuai dengan materi pada pokok bahasan yang dipelajari. Salah satu alternatif metode pembelajaran yang bisa diterapkan adalah pendekatan struktural dengan metode "Think-PairShare" (TPS) pada pokok bahasan faktorisasi suku aljabar.

b. Dalam proses belajar mengajar matematika perlu memperhatikan pada pentingnya kreativitas belajar matematika siswa. Kreativitas belajar matematika siswa dapat tumbuh atau berkembang dari rumah, sehingga guru dapat menumbuhkan, mengarahkan dan membimbing siswa agar memiliki kreativitas belajar matematika yang baik.

c. Dalam proses belajar mengajar hendaknya guru memperhatikan kreativitas siswa, misalnya dengan cara memilih dan menggunakan metode pembelajaran yang lebih banyak melibatkan kreativitas siswa.

2. Bagi Siswa

a. Setiap orang mempunyai kreativitas yang berbeda-beda dan dapat dikembangkan. Oleh karena itu siswa dapat mengembangkan kreativitas yang dimilikinya yang salah satunya adalah dapat dikembangkan dalam kegiatan pembelajaran.

b. Siswa hendaknya selalu berusaha untuk menumbuhkembangkan kreativitas belajar dalam dirinya, karena dengan kreativitas tinggi dapat meningkatkan prestasi belajar siswa.

c. Siswa hendaknya dalam kegiatan pembelajaran lebih aktif, berani mengungkapkan ide yang ada dalam fikirannya dan tidak mudah putus asa dalam menyelesaikan suatu permasalahan dalam soal.

3. Bagi Peneliti lain

a. Dalam penelitian ini metode pembelajaran ditinjau dari kreativitas belajar matematika siswa. Bagi para calon peneliti yang lain mungkin dapat melakukan tinjauan yang lain, misalnya gaya belajar, karakteristik cara berpikir, motivasi, aktivitas, minat siswa, intelegensi dan lain-lain agar dapat lebih mengetahui faktor-faktor 
yang mempengaruhi prestasi belajar matematika siswa.

b. Hasil penelitian ini hanya terbatas pada pokok bahasan faktorisasi suku aljabar di SMP, sehingga mungkin bisa dicoba diterapkan pada pokok bahasan yang lain dengan mempertimbangkan kesesuaiannya.

\section{DAFTAR PUSTAKA}

Budiyono. (2003). Metodologi Penelitian Pengajaran Matematika. Surakarta: UNS Press. (2004). Statistika Dasar Untuk Penelitian. Surakarta: UNS Press.

Carss, Wendy Diane. (2007). "The Effects of Using Think-Pair-Share During Guided Reading Lessons". Thesis: The University of Waikato.

Departemen Pendidikan dan Kebudayaan. (2005). Kamus Besar Bahasa Indonesia. Jakarta: Balai Pustaka.

De Porter, Bobby \& Nourie, Singer, Sarah. (2001). Quantum Teaching: Mempraktekkan Quantum Learning di Ruang-Ruang Kelas. Terjemahan Ary Nilandari. Bandung: Kaifa.

Enny Semiawan, S. Munandar, CU Munandar. (1984). Memupuk Bakat dan Kreativitas Siswa Sekolah Menengah. Jakarta: PT. Gramedia.

Galligan, Ann. (2006). Art, Culture and The National Agenda. Washington, D.C. In The Journal of Creativity, Culture, Educational, and The Workforce, Volume 5, Number 1, pp. 20-21. (www.culturalpolicy.org)

Gonzales, Patrics. (2008). Highlights From TIMSS 2007: Mathematics and Science Achievement of U.S. Fourth- and Eighth-Grade Students in an International Context . National Center for Education Statistics, U.S. Department of Education. Washington, DC. (http://nces.ed.gov/pubsearch/pubsinfo.asp?pubid=2009001)

Human Development Reports. (2008). The Human Development Index-Going Beyond Income Washington, DC

(http://hdrstats.undp.org/2008/countries/country_fact_sheets/cty_fs_IDN.html)

Idris, Noraini. (2009). Enhancing Students' Understanding In Calculus Trough Writing. Faculty Of Education, University Of Malaya Kuala Lumpur, Malaysia. International Electronic Journal Of Mathematics Education, Volume 4, Number 1, pp. 39-40. (www.iejme.com).

Kennedy, Ruth. (2007). In-Class Debates: Fertile Ground for Active Learning and the Cultivation of Critical Thinking and Oral Communication Skills. Bloomsburg University of Pennsylvania. International Journal of Teaching and Learning in Higher Education, Volume 19, Number 2, pp. 183-190. (http://www.isetl.org/ijtlhe/)

Lie, Anita. (2002). Cooperative Learning Mempraktikkan Cooperative Learning di Ruang-Ruang Kelas. Yogyakarta: PT.Grasindo.

M. Nur. (2005). Pembelajaran Kooperatif. Surabaya: Pusat Sains dan Matematika Sekolah UNESA. 
Muhibbin Syah. (1995). Psikologi Pendidikan: Suatu Pendekatam Baru. Bandung: Remaja Rosdakarya.

Nursisto. (2000). Kiat Menggali Kreativitas. Yogyakarta: Mitra Gamawidya.

Oemar Hamalik. (1989). Psikologi Belajar Mengajar. Bandung: Sinar Baru Algesindo.

Pargiyo. (2000). Telaah Kurikulum Matematika SMU. Surakarta: UNS Press.

Paul Suparno. (1997). Filsafat Konstruktivisme dalam Pendidikan. Yogyakarta: Kanisius.

Purwoto. (2003). Strategi Pembelajaran Mengajar. Surakarta: UNS Press.

Pupendik Balitbang-Depdiknas. (2008). Laporan Ujian Nasional SMP Tahun 2008. Jakarta.(http://puspendik.info/v4/index.php?option=com_jdownloads\&Itemid=200080\&task=s $\underline{\text { ummary \&cid }=7 \& \text { catid }=3 \& \text { lang }=\mathrm{id} \text { ) }}$

Russeffendi E.T. (1984). Dasar-dasar Matematika Modern dan Kompetensi Untuk Guru. Bandung: Tarsito.

Slameto. (1995). Belajar dan Faktor-faktor yang Mempengaruhinya. Jakarta: PT Rineka Cipta.

Slavin, Robert E. 2009. Psikologi Pendidikan, Teori dan Praktik. Jakarta: PT Indeks.

Stevens, R.J., \& Slavin, R.E. 1995. Effects of a cooperative learning approach in reading and writing on academically handicapped and nonhandicapped students. Palmerston North. The Elementary School Journal, Volume 95, Number 3, pp. 22-23.

Suharsimi Arikunto. 1998. Prosedur Penilaian. Jakarta: PT. Rineka Cipta.

2002. Prosedur Penelitian, Suatu Pendekatan Praktek, Edisi Revisi V. Jakarta: PT. Rineka Cipta.

Sutratinah Tirtonegoro. 2001. Anak Supernormal dan Program Pendidikannya. Jakarta: PT. Bumi Aksara.

Tengku Zahara Djaafar. (2001). Kontribusi Strategi Pembelajaran Terhadap Hasil Belajar. Jakarta: Depdiknas

Trianto. (2007). Model Pembelajaran Terpadu dalam Teori dan Praktek. Jakarta: Prestasi Pustaka Publisher.

Umi Andriyati. (2007). Eksperimentasi Pembelajaran Matematika Dengan Metode RME (Realistic Mathematics Education) ditinjau dari kreativitas Belajar Matematika Siswa, Skripsi. Surakarta: FKIP UNS.

Utami Munandar. (2004). Memupuk Bakat dan Kreativitas Siswa Sekolah Menengah. Jakarta: PT. Gramedia.

Winckler, Georg. (2007). Creativity in Higher Education. Belgia. The Journal of Creativity in Higher Education, Volume 1, Number 1, pp. 16-17. (www.eua.be)

Winkel, W.S. (1996). Psikologi Pengajaran. Jakarta: Gramedisa Widiasarana Indonesia.

Zainal Arifin. (1990). Evaluasi Instruksional. Bandung: Remadja Karya. 